\title{
RELATIONS BETWEEN SOIL CHEMICAL PROPERTIES AND CADMIUM CONTENT IN GREEN MASS OF SILAGE MAIZE
}

\author{
Mirha ĐIKIĆ ${ }^{1 *}$, Emir DŽOMBA ${ }^{1}$, Drena GADŽO ${ }^{1}$, Teofil GAVRIĆ ${ }^{1}$, \\ Jasmin GRAHIĆ ${ }^{1}$, Dženan HADŽIĆ ${ }^{1}$, Bal Ram SINGH ${ }^{2}$
}

\begin{abstract}
Cadmium content in soil is an important factor which determines the content of this heavy metal in plants. However, many other factors including soil $\mathrm{pH}$, content of organic matter, other trace minerals in soil which could reduce or enhance cadmium uptake by roots of plants as well as anthropogenic routes of cadmium contamination (mining, superphosphates and industry) can have an influence on the cadmium concentrations in plant tissue. A three years study was conducted to evaluate cadmium content in green mass of silage maize in certain areas of Central Bosnia region. A multiple linear regression (MLR) model was developed to predict maize tissues cadmium concentration as function of different factors such as soil cadmium content, $\mathrm{pH}$ of soil, organic matter in soil as well as phosphorus, potassium, zinc and iron content in soil. The results indicate huge variability of cadmium content in soil (maximum value was more than 3 fold greater than the minimum value) and green mass of maize (maximum to minimum ratio greater than 100). Cadmium concentration in all investigated samples of maize was below maximum tolerable levels in ruminant nutrition. Using a stepwise multiple linear regression method, a significant model emerged $\left(\mathrm{F}_{2.14}=55.193, \mathrm{p}<0.001 ; \mathrm{R}^{2}=0.887\right)$. Significant variables were phosphorus $($ Beta $=0.813, \mathrm{p}<0.001)$ and potassium $($ Beta $=-0.401, \mathrm{p}<0.005)$ content in soil. Soil $\mathrm{pH}$, organic matter, cadmium, zinc and iron were not significant in this model. Insignificant correlation between soil and plant cadmium content $(r=0.374, p=0.07)$ indicates that the presence of cadmium in the soil may not be the main determinant of its content in plants.
\end{abstract}

Keywords: cadmium, soil chemical.properties, silage maize, $M L R$

\footnotetext{
${ }^{1}$ Faculty of Agricultural and Food Sciences, University of Sarajevo, Zmaja od Bosne 8, 71000 Sarajevo, Bosnia and Hercegovina

${ }^{2}$ Norwegian University of Life Science, As, Norway

*Corresponding author: m.djikic@ppf.unsa.ba
} 


\section{INTRODUCTION}

Cadmium $(\mathrm{Cd})$ accumulates in plants grown in high-cadmium soils. Natural cadmium levels found in phosphates from sedimentary rocks range from 3 to $100 \mathrm{mgkg}^{-1}$ depending on their location (Singh, 1994). Additionally, annual application of phosphorus fertilizers is a significant source of $\mathrm{Cd}$ in the agricultural soils. Phosphate fertilizers, among all mineral fertilizers, are generally the major source of cadmium (McLaughlin et al., 1996). Also, atmospheric deposition of cadmium on the surface of soil and plants are recognized as important factor of food chain contamination. Data copied from EU risk assessment report implies that the cadmium atmospheric deposition ranged between 0.15 and $4 \mathrm{~g} / \mathrm{ha} /$ year for 2002 (EU, 2007). Total soil cadmium content is not a good indicator of cadmiums migration possibility into plant tissue. The amounts of cadmium uptake by plants depends on many factors including soil texture, content of organic matter, $\mathrm{pH}$ of soil and the amount of rainfall (Jeng and Singh, 1995). Namely, these factors combined determine the ratio of cadmium leaching from soil and its uptake by plants. Additionally, it seems that the plant genotype can have an influence on the cadmium accumulation in plant tissue (Lehoczky and Kiss, 2006). Cadmium mostly accumulates in kidneys, but higher concentration can be found in liver, testes, pancreas and spleen of animals (and humans) as well, expressing cumulative toxic effect (NRC, 2005). Short term assessing of cadmium concentrations in food chain does not offer a valid picture of cadmium food contamination. Many factors influence the long-term accumulation of cadmium in the body making it difficult to evaluate the effect of different factors that contribute to cadmium contamination in different areas. Therefore, the aim of this study was to discriminate the most important factors (fertilizer, soil, $\mathrm{pH}$ and organic matter) that influence the cadmium content in maize.

\section{MATERIAL AND METHODS}

The research was conducted in four areas of the Central Bosnia region (Figure 1) which differ in agricultural practice, level of industrialization, urbanization and soil properties.

The crops chosen for this study were maize and green mass of natural pastures which serve as the major feedstuff at local dairy and sheep farms. Periodically, during three years, soil and animal feed samples were collected from each of the selected areas. Soil samples were taken using a stainless steel shovel from the depth of $0-20 \mathrm{~cm}$, in which the roots of crops mainly distribute. Each soil sample consisted of up to ten subsamples taken from an area of ca $500 \mathrm{~m}^{2}$. Five whole plants of maize per locality were ground and mixed after which the biomass sample was taken. The samples were dried and sifted prior to the determination of $\mathrm{pH}$, potassium, phosphorus, iron and zinc as well as organic matter content in the soil and total cadmium content in soil and plants. 


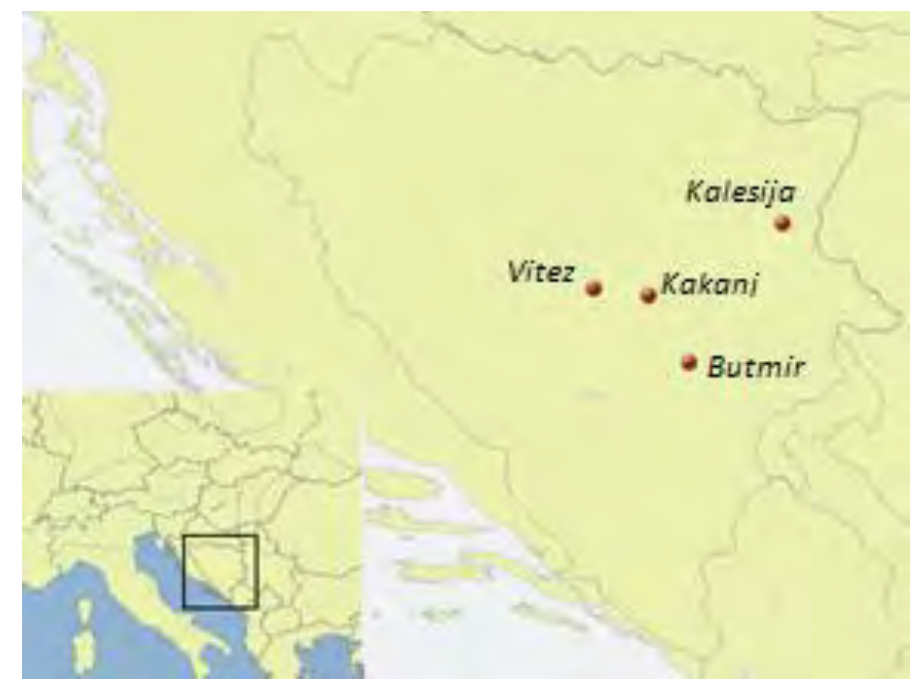

Figure 1. Map of selected localities

Soil $\mathrm{pH}$ was determined in a water solution (ISO 10390, 1994). SOC was determined by wet combustion of organic matter in $\mathrm{H}_{2} \mathrm{SO}_{4}$ and $\mathrm{K}_{2} \mathrm{Cr}_{2} \mathrm{O}_{7}$ - dichromate method (Mineev et al., 2001). Soil potassium and phosphorus content were determined according to AL by ammonium lactate-acetic acid extraction described by Egner et al. (1960). The content of extracted phosphorous is measured calorimetrically and the content of potassium by flame photometry. Inductively Coupled Plasma Mass Spectrometer (ICP-MS) was used to determine total cadmium content in substrates, while the total content of iron and zinc in soil was determined by Inductively Coupled Plasma Optic Emission Spectrometer (ICPOES) after wet digestion of samples in ultra-pure $\mathrm{HNO}_{3}$.

A multiple linear regression (MLR) model was created using the software package SPSS 17 in order to predict maize tissues cadmium concentration as function of different factors such as soil cadmium content, $\mathrm{pH}$ of soil, organic matter in soil as well as phosphorus, potassium, zinc and iron content in soil.

\section{RESULTS AND DISCUSSION}

Results of the soil properties and concentration of trace minerals in soil and whole plants of maize are presented in Table 1. 
Table 1. Some indicators of soil quality and trace elements content in soils and plants at investigated localities

\begin{tabular}{|c|c|c|c|c|c|}
\hline & \multicolumn{4}{|c|}{ Locality } & \multirow{2}{*}{ Average } \\
\hline & Kalesija & Vitez & Kakanj & Butmir & \\
\hline $\mathrm{pH}\left(\mathrm{H}_{2} \mathrm{O}\right)$ & $5.96 \pm 0.60$ & $7.00 \pm 0.28$ & $7.93 \pm 0.08$ & $6.45 \pm 0.21$ & $6.83 \pm 0.29$ \\
\hline pH (KCl) & $4.77 \pm 0.67$ & $6.05 \pm 0.35$ & $7.22 \pm 0.05$ & $5.07 \pm 0.28$ & $5.77 \pm 0.34$ \\
\hline $\mathrm{P}_{2} \mathrm{O}_{5}, \mathrm{mg} / 100 \mathrm{~g}$ & $1.27 \pm 1.27$ & $7.95 \pm 9.12$ & $2.99 \pm 2.14$ & $16.79 \pm 1.22$ & $7.25 \pm 3.44$ \\
\hline $\mathrm{K}_{2} \mathrm{O}, \mathrm{mg} / 100 \mathrm{~g}$ & $37.33 \pm 19.33$ & $56.60 \pm 48.79$ & $36.37 \pm 14.26$ & $17.64 \pm 1.32$ & $36.98 \pm 20.92$ \\
\hline O. matter, \% & $2.9 \pm 0.66$ & $2.80 \pm 0.71$ & $3.38 \pm 0.58$ & $4.30 \pm 0.01$ & $3.34 \pm 0.49$ \\
\hline Cd soil, $\mathrm{mg} / \mathrm{kg}$ & $0.56 \pm 0.04$ & $1.09 \pm 0.52$ & $0.51 \pm 0.06$ & $0.62 \pm 0.09$ & $0.70 \pm 0.18$ \\
\hline Zn soil, mg/kg & $71.18 \pm 13.49$ & $91.82 \pm 41.12$ & $95.43 \pm 24.53$ & $68.75 \pm 3.28$ & $81.79 \pm 20.60$ \\
\hline Fe soil, mg/kg & $35846 \pm 12658$ & $30845 \pm 2821$ & $31910 \pm 7110$ & $23740 \pm 1364$ & $30585 \pm 598$ \\
\hline Cd plant, mg/kg & $0.001 \pm 0.000$ & $0.006 \pm 0.006$ & $0.023 \pm 0.013$ & $0.098 \pm 0.013$ & $0.032 \pm 0.08$ \\
\hline
\end{tabular}

Soil $\mathrm{pH}$ ranged from 5.96 to 7.93 , mean value $6.83 \pm 0.29$. It varied from alkaline to slightly acidic. The organic matter content was also variable and generally all the soils had moderate content of humus whereby the soils at Butmir and Kakanj were much richer in humus comparing to soils at Vitez and Kalesija sites. Content of phosphorous varied widely in the studied soils indicating different agronomic practice (intensity of fertilization) among investigated sites. $\mathrm{Cd}, \mathrm{Zn}$, and Fe contents in the studied soils differed markedly between sites. The Pearson correlation matrix for all investigated parameters is shown in Table 2.

Table 2. Pearson correlation matrix for total soil and plant properties

\begin{tabular}{|c|c|c|c|c|c|c|c|c|}
\hline & Cd plant & $\mathbf{p H}$ & $\mathrm{P}_{2} \mathrm{O}_{5}$ & $\mathrm{~K}_{2} \mathrm{O}$ & O. matter & Cd soil & Zn soil & Fe soil \\
\hline Cd plant & 1,000 & & & & & & & \\
\hline pH & -0.233 & 1,000 & & & & & & \\
\hline $\mathrm{P}_{2} \mathrm{O}_{5}$ & $0.854 * * *$ & -0.334 & 1,000 & & & & & \\
\hline $\mathrm{K}_{2} \mathrm{O}$ & $-0.483 *$ & 0.194 & -0.101 & 1,000 & & & & \\
\hline O. matter & $0.753 * * *$ & -0.025 & $0.675^{* * *}$ & -0.261 & 1,000 & & & \\
\hline Cd soil & 0.374 & $-0.49 *$ & 0.28 & $-0.488 * *$ & 0.077 & 1,000 & & \\
\hline Zn soil & -0.169 & $0.503^{*}$ & -0.073 & 0.317 & 0.302 & -0.404 & 1,000 & \\
\hline Fe soil & -0.398 & 0.191 & -0.41 & 0.145 & 0.064 & -0.265 & $0.646^{* *}$ & 1,000 \\
\hline
\end{tabular}

${ }^{* * * * * * ; *}$ Correlation is significant at the $0.001,0.01$ and 0.05 level respectively 
Phosphorus and organic matter content in soil increase cadmium content in maize $(\mathrm{p}<0.001)$ and these strong associations are in line with the statement that the cultivated areas were contaminated by cadmium through different agricultural practice. This is opposite to findings of Ramachandran and D'Souza (1998) who stated that organic matter can regulate the availability of heavy metals through chelation reaction and that the complex compounds of trace elements with organic material are unavailable for plants. In this case positive organic matter and $\mathrm{Cd}$ relationship could be explained by the fact that the increase of organic matter in the soils is accompanied by intense adding of $\mathrm{P}$ fertilizers. Strong correlation $(\mathrm{r}=0.575, \mathrm{p}<0.001)$ between organic matter and phosphorus content in soil is in line with this statement. At the same time, negative moderate correlation $(\mathrm{r}=-0.483 ; \mathrm{p}<0.05)$ was observed between potassium content in soil and cadmium concentrations in the plant.

Using the stepwise method, a significant model emerged $\left(\mathrm{F}_{2.14}=55.193, \mathrm{p}=0.000\right.$, Adj. $\left.\mathrm{R}^{2}=0.871\right)$. Significant variables are shown in Table 3. Organic matter, $\mathrm{pH}$, as well as soil trace elements content were not a significant predictor in this model.

Table 3. Stepwise logistic regression model predicting the cadmium content in the whole maize plant.

\begin{tabular}{lcc}
\hline & Beta & P \\
\hline \hline Variables included in the model & & \\
\hline Constant & 0.03 & 0.002 \\
\hline $\mathbf{P}_{2} \mathrm{O}_{5}$ & 0.813 & 0.000 \\
\hline $\mathrm{K}_{2} \mathrm{O}$ & -0.401 & 0.001 \\
\hline
\end{tabular}

Two primary factors that influenced the variability of cadmium content in the plant are the presence of phosphorus and potassium in the soil. $87.1 \%$ of total cadmium variability in maize plants could be explained by these two elements. Increasing phosphorus in the soil led to increase of cadmium content in plants which is in line with many earlier findings (Jeng and Singh, 1995; McLaughlin et al., 1996; Andresson and Siman, 1991). Nziguheba and Smolders (2008) showed that in 2008 the $\mathrm{Cd}$ concentration in the $\mathrm{P}$ fertilizers used in Europe had an average value of $36 \mathrm{mg} \mathrm{Cd}(\mathrm{kg}$ $\left.\mathrm{P}_{2} \mathrm{O}_{5}\right)^{-1}$. Therefore, the application rate of the mentioned mineral fertilizer $\left(\mathrm{kg} \mathrm{P}_{2} \mathrm{O}_{5}\right.$ ha $^{-1}$ $\mathrm{yr}^{-2}$ ) is a crucial parameter in determining the Cd input from fertilizers.

Results of potassium and cadmium correlation (Table 2 and Table 3) indicate that increasing $\mathrm{K}_{2} \mathrm{O}$ content in soil led to the decrease of cadmium content in the plants. Although this relationship is weak $(r=0.483$ and Beta $=-0.401)$ it seems that presence of potassium in soil cold interference cadmium uptake by plants. 
Ciećko et al. (2004) found that soil contamination with cadmium caused an increase or a decrease in the content of potassium, depending on the plant species and organ, which indicates a possible correlation between these two elements, but it seems that this also depends on the physical and chemical properties of the soil. Namely, solubility of cadmium is associated with $\mathrm{pH}$ of soil and according to Sauve et al. (2000) $60 \%$ of the cadmium variability in soil solution phase could be explained by soil $\mathrm{pH}$. In this study significant negative correlation coefficient $(\mathrm{r}=-0.49)$ between soil $\mathrm{pH}$ and cadmium content in the soil was observed (Table 2).

\section{CONCLUSIONS}

Although that the research was based on a limited number of inputs (localities, number of samples, limited factors indicating soil quality), soil phosphorus and potassium content are the factors that could be used for prediction of cadmium content in plants. Significant negative correlations were observed between soil $\mathrm{pH}$ and soil $\mathrm{Cd}$ content which implies that the availability of $\mathrm{Cd}$ for its uptake by roots of plant could become lower with the increase of soil $\mathrm{pH}$. On the other hand, significant positive correlation between organic matter and $\mathrm{Cd}$ content in soil indicates that increased fertilizer application could lead to $\mathrm{Cd}$ contamination.

\section{Acknowledgements}

This study is part of the project "Mineral Improved Food and Feed Crops for Human and Animal Health (project number 332160UA)", which was supported by a grant from the Norwegian Ministry for Foreign Affairs under the Program for Higher Education, Research and Development (HERD) in Western Balkan. The financial and technical assistance from the project is gratefully acknowledged.

\section{REFERENCES}

Andersson, A. and G. Siman. 1991. Levels of Cd and some other trace elements in soils and crops as influenced by lime and fertilizer level. Acta Agriculture Scandinavica, 41:3-11.

Ciećko, Z., S. Kalembasa, M. Wyszkowski and E. Rolka. 2004. Effect of soil contamination by cadmium on potassium uptake by plants. Polish Journal of Environmental Studies, 13-3, 333-337.

Egner, H., H. Riehm, W.R. Domingo. 1960. Untersuchungen uber die chemische Bodenanalyseals Grundlage fur die Beurteilung de Nahrstoffzustandes der Boden. II. K. LantbrHogsk. Ann., 26: 199-215.

EU 2007. European Union risk assessment report. Cadmium metal. Part I Environment. Statistics by the European Commission. 
Jeng, A.S. and B.R. Singh. 1995. Cadmium status of soils and plants from a long-term fertility experiment in southeast Norway. Plant and Soil, 175: 67-74.

Lehoczky, E. and Z. Kiss. 2006. Study of the transfer coefficient of cadmium and lead in ryegrass and lettuce. Communications in Soil Science and Plant Analysis, 37: 2531-2539.

McLaughlin, M.J., K.G. Tiller, R. Naidu, D.P. Stevens. 1996. The behavior and environmental impact of contaminants in fertilizers. Australian Journal of Soil Research, 34: 1-54.

Mineev, V.G., V.G. Sićev, O.A. Ameljačkin. 2001. Praktikum po Agrohimi. Izd. Moskov. Uni, 215-217.

NRC - Committee on Minerals and Toxic Substances in Diets and Water for Animals. 2005. Cadmium. In: Mineral tolerance of animals. $2^{\text {nd }}$ revised edition, pp 79-97.

Nziguheba, G., E. Smolders. 2008. Inputs of trace elements in agricultural soils via phosphate fertilizers in European countries. Science of the Total Environment, 390: 53-57

Ramachandran, V. and T. J. D’Souza. 1998. Plant Uptake of Cadmium, Zinc, and Manganese in Soils Amended with Sewage Sludge and City Compost. Bulletin of Environmental Contamination and Toxicology, 61-3, pp 347-354.

Sauvé S., W. Hendershot and H.E. Allen. 2000. Solid-solution partitioning of metals in contaminated soils: dependence on $\mathrm{pH}$, total metal burden, and organic matter. Environmental Science \& Technology 34 (7), 1125-1131.

Singh, B. R. 1994. Trace element availability to plants in agricultural soils, with special emphasis on fertilizer inputs. Environ. Rev. 2:133-146. 